\title{
Concept of Non Healing Ulcers in Unani System of Medicine: A Review
}

\author{
Khalid Ali Khan ${ }^{1 *}$, Rashid Ali Khan ${ }^{2}$
}

${ }^{1}$ Associate Professor, Deptt. of Ilmul Jarahat, Rajputana Unani Medical College Hospital \& Research Centre, Jaipur Rajasthan India

${ }^{2}$ Associate Professor \& H. O. D. Deptt. of Amraz e Jild-o-Zohrawiya wa Tajeeniyat University College of Unani, Tonk Rajasthan India

DOI: $10.36347 /$ sasjs.2020.v06i03.006

| Received: 01.03.2020 | Accepted: 09.03.2020 | Published: 14.03.2020

*Corresponding author: Khalid Ali Khan

\section{Abstract}

In Unani system of Medicines description of the wound is given in details. Wounds are called Qurūh and their type, causes and management and different stages of healing are well documented. There are so many types of ulcers/wounds described in Classical literature of Unani. Qurūh Usrahandamal and Qurūh Kheronia are type of ulcer/wounds mentioned in literature as the ulcers which are difficult to heal. These ulcers are bad in nature and are difficult to manage. According to Jalinos (Galen) Qurūh Kheronia is named after the person who was suffered with this type of ulcer first time and he was a physician. There are more than ten causes described by the Unani physician for non-healing ulcer or wound. The specific sign and symptoms and management of each and every ulcer/wound are given in detail.

Keywords: Healing, Jarahat, Non healing ulcers, Quruh, Unani, Usrahandamal, Wound.

Copyright @ 2020: This is an open-access article distributed under the terms of the Creative Commons Attribution license which permits unrestricted use, distribution, and reproduction in any medium for non-commercial use (NonCommercial, or CC-BY-NC) provided the original author and source are credited.

\section{INTRODUCTION}

Skin play protective role to save the inner tissues and cells from the hazards of the environment. Ulcer or wound is breaking of the protective layer and exposure of the delicate tissues and cells to the environment. Ulcer or wound generally caused by any injury or accident and common condition worldwide. The healing of the wound by natural healing process is carried out by body defence system. There are different stages of the healing and each stage follows its pattern. Sometime due to many reason the healing process delayed very long and wound/ulcer doesn't heal in due course of time. In some cases even it increases in size and gets infected and inversely affects general body health of the person. There are certain conditions and some diseases like diabetes where healing delayed due to various reasons. Non healing ulcers/wound is described in detail in classical literature of the Unani System of Medicine. Detail etiology, sign and symptoms and managements are described by Unani physicians. Qurūh Usrahandamal and Qurūh Kheronia are the name given to the ulcer/wound which doesn't heal at normal speed and takes more than usual time [1, 2, 3, 6, 7].

Causes, sign \& symptoms and management of Qurūh Usrahandamal and Qurūh Kheronia:

The following causes of non-healing ulcer/wound, sign and symptoms and management is given as per Unani classical literature. Jalinos (Galen) has described these ulcer/wound and other Unani physicians also described these in details:

Qillat-i-Dam (low quantity of the blood in the body), the primary function of blood is to supply the nutrient to the ulcer. It provides raw material which transform into cells of the tissue at the site of ulcer and replace the dead cells with the help of Quwwat Mughayyira (transformative faculty) of the body.

The sign of Qillat-i-Dam is lack of redness in and around the ulcer; no sign of inflammation is there, dryness is dominant at ulcer and patient will be physically weak.

In this case Dalk (massage) is recommended around the ulcer or wound to improve blood supply at the site. It may also be achieved by Tikor (hot fomentation) by hot water with the help of cotton cloth. Muqawwi Ghiza (balance and high protein diet) should be used to improve immunity and function of the body and to increase blood quantity and quality in the body. Marham-i-Aswad may be used which is made up of Zift, Ratenaj, Shakar, and Roghan-i-Zetoon. Marham-iAswad facilitates transport of the blood to the ulcer site and also improves healing process. Hot fomentation by water increase flow of blood towards ulcer and improve healing process [1-3]. 
Raddi 'uddam: in this condition blood of the body becomes impaired (like putrid matter) and when it reaches the ulcer it will not transform into new cells else it will convert into impurities in ulcers.

The sign of Raddi 'uddam includes pale or white colour of the body if liver is involved. In case of impairment of Mizaj of spleen the colour of body will be blackish and black spots will be present on the body.

In this condition Fasd (Venesection) and Ishal (Purgation) is used to remove Fasid Madda (putrid matter) from the body. The drugs to improve the Mizaj (temperament) of Liver and spleen should be used [13].

Zof-e Quwwat (weakness): The innate power of organ becomes weak and not able to digest and convert the food into cells or tissue [1-3].

Zof-e Quwwat due to Sū'-i-Mizāj Hārr (Impaired Hot temperament), in this condition either temperament of organ or whole body become hot due to impairment.

The sign of this condition is that redness; itching and severe pain will be present in affected part. Here Fasd (Venesection) of appropriate vein should be done according to the site of ulcer. Adequate blood may be removed from the body to normalise the hot temperament. Cold food items may be used; cold Marham like Marham-i-Kafoor may be used. Sard Tila (cold liniment) may be used around the ulcer.

Zu'fal-Quwwat (weakness) due to $S \bar{u}$ '-i-Mizāj Bārid (Impaired cold temperament), in this condition temperament of the body become cold due to impairment.

The sign of this condition is the colour of the body become bluish due to lack of fresh and pure blood. There will be lack of heat in the body.

Here Garm ghiza (hot food items) should be used like Maul laham (distillate of meat) and Anjeer and Mavez Munaqqa with hot spices. Hot fomentation may be used and Marham-i-Basliqoon and Marham- $i$ Siyah may be used. Marham-i-Basliqoon is made by these crude drugs i.e. Zift, Ratenaj, Bahroza, Mom and Roghan-i Zaitoon. Marham-i-Siyah is made up of Murdar Sang, Kundur, Dammul Akhwain, Anzaroot and Roghan-i Zaitoon.

Zu'f al- Quwwat due to $S \bar{u}$ '-i-Mizāj Ratb (Impaired moist temperament), in this condition Mizaj (temperament) of the body become moist due to impairment and Fi'l-i-Thagziya' (act of assimilation) become weak.
Moistness and water will be more in ulcer and tissue around ulcer will be loose. Tanqiya (evacuation) of morbid matter by Halela and Turbud is recommended in this type of ulcers. Dry food item should be used like roasted meat etc. Use Marham which have drying properties like Marham made up of Gulnar, Mazu, Tanba Sokhta, Haldi, Sendur, Fitkari, Murdar Sang and Roghan-i Zaitoon.

Zu'f al- Quwwat due to Sü'-i-Mizāj Yābis (Impaired dry temperament), in this condition Mizaj temperament of the body become dry due to impairment.

The ulcer is dry and healing becomes delayed due to dryness and lack of liquid. Here Tikor (fomentation) by warm water and Roghan Banafsha are recommended. Diet with high liquid should be used like Hareera, Shorba (Soup/broth) and half boiled eggs. Marham having low drying properties should be used e.g. Marham made by Ard Karasna.

Lahm Sulb (Hard flesh), sometimes healing delayed due to presence of hard flesh in or around the ulcers which prevent meeting of ends of ulcers. In this condition hardness of flesh will be felt when touched and presence of hard flesh is around the margins of the ulcers.

Hard flesh should be removed by surgery or by application of Akkal (corrosive) drugs like Farfiyun on it. After that Marham which have healing properties should be used [1-3].

'Azm-i- 'Ufūn Fāsid (Infected and putrid bone), sometimes a putrid and infected bone may be present in deep of the ulcer and due to secretion of infected fluid from bone which hinder healing of the ulcer.

In this condition ulcer/wound may be healed but again it emerges. Pus and yellow liquid with foul smell will be present in the ulcer/wound. Flesh of the wound become loose and become putrid.

Here a deep incision to be made to reach out to the bone and Akkal (corrosive) drugs should be applied so that it destroy putrid and dead tissue around the bone, after that bone is peeled by sharp knife so infected part is removed. This process is only possible when whole bone in not putrefied. Sometimes surgery is done to remove putrid bone and after that Zaroor (dusting powder) made up of Mur Makki, Aelwa and Kundur, is used for healing purpose [1, 2, 3, 5].

'Ufünat aur Khabs (infection): Sometime ulcer doesn't heal due to presence of infection at the site of wound and when blood reaches here it got deranged. This deranged blood doesn't allow healing. 
In this condition the ulcer/wound become blackish and increases in size. Here Zimad (paste) made up of Berg Kasni, Berg Khatmi and Mako may be applied to remove putrid flesh. Tanqiya (evacuation) of deranged matter from the body may be done by proper drugs. First of all identify the Khilt (humour) involved in it and use appropriate drugs accordingly to evacuate khilt raddi (deranged humour) [1, 2, 3, 5].

Kasrat-i Maiyat (excess of fluid), in this condition the flesh become deranged and loose due to excess fluid at the site of the wound. This condition is similar to the condition of ascites.

The wound/ulcer will be moist and loose. Here the deranged flesh may be removed by Akkal (corrosive) drugs and Ghee (clarified butter). Thereafter Marham having healing properties should be used [1-3].

Dawālì (varicose veins), in this condition the veins near the ulcer/wound are dilated and fluid supply to the wound is more than normal which delays healing.

The presence of varicose veins near the ulcer/wound is visible. Fasd (Venesection) is recommended and Ishal (purgation) by Joshānda Aftimoon is used after that. Moderate food may be used and Fasd (Venesection) in varicose vein is done to remove blood from these veins so that Rutubat (moistness) may be prevented to reach at ulcer site [1, $2,3,7]$.

Adam Muwafiqat-i Advia (intolerance of drugs used), sometimes drug used for healing doesn't suit the body or even worsen the condition of ulcer/wound [13]:

1. In case of dominance of Harārat (hotness) due to use of Harr Marham (hot cream) healing delayed due to increased heat. Harārat (hotness) in the wound attract deranged matter from surrounding tissues and affected tissue has not able to deal with this matter and healing delayed.

In this condition the wound has redness, itching and swelling.

Barid (Cold) Marham may be used to avoid exaggeration of the ulcer [4].

2. In case of dominance of Burudat (coldness) due to use of cold drugs the Quwwat (power) of the tissue become weak \& slow. In this condition neither Ghiza (food) reaches here nor did its transformation take place completely.

The wound become becomes cold, hard and bluish in colour.

Marham-i-Siyah may be used; it has Harr Mizaj (hot temperament) and also has the ability to attract bloods toward the affected area [4,5].

3. Tanqiya ki kami (lack of proper evacuation of morbid matter), sometimes Marham (ointment) has not cleaned the wound due to low detergent capacity so healing delayed.

In this case wound will be dirty and contain putrefied tissues in and around it.

Here Marham having strong Munaqqi (evacuation) property should be used. Marham made up of Zangar and Honey can be used here as it has detergent as well as corrosive activity also.

4. Tajfif ki Kami (lack of dryness), If drugs are unable to dry the wound then it contains more fluid and become loose.

In this condition Marham having healing capacity with more drying ability may be used. Marham having Mazu and Gulnar can be used here [5].

5. Laza ki ziyadti (excessive irritation) if drugs due to their property of Jila (irritant) causes death of tissues and convert it into pus.

Here pain, swelling and heat will be more in wound and it increases day by day.

In this case soft Marham having moderate heat and dryness can be used and it should not posses' irritant property [4].

Mawād-i Fuzul (deranged matter), the body have deranged matter which comes toward wound and prevent healing.

In this type of wound foreign matters are seen in wound and it looks dirty. First of all Tanqiya (evacuation) with Joshānda Halela may be done after that Mujaffif (desiccant) drugs should be used to increase healing process of the wound/ulcer. Light diet should be taken [1-3].

\section{REFERENCES}

1. Nafis ibn 'Iwad ibn Jamal al-Din al-Mutatabbib alKirmani, [1439 AD], Sharh al-Asbab wa'l 'Alamat, Vol. III-IV, (urdu translation by Hakim Kabīruddīn), Aijaz Publishing House, New Delhi, 305-309.

2. Ibn Sīnā, al-Shaykh al-Ra'īs Abū 'Alī al-Husayn ibn 'Abd Allāh (1411AH): Al-Qānūn fi'l Tibb, Idara Kitabul Shifa, New Delhi. 1319-1323.

3. Arzān̄̄ MA. Tibb-e-Akbar Urdu, Faisal Publisher, Jama Masjid, Deoband. 1924, 772-778.

4. Arzani MA, Meezan al-Tib, National Council for promotion of Urdu language, New Delhi. 1992: 248-252.

5. Jurjani, Sharaf al-Din Isma'il ibn Husayn [d.1135 AD], Zakhira Khawarizm Shahi, Idara Kitabul Shifa, New Delhi. 2010, 47-48.

6. Majūsī, 'Ali ibn 'Abbās, Kāmil al-Sanā'a, Vol.I, Idara Kitabul Shifa, New Delhi. 437-438

7. Qamri, AMA, Ghana Mana, urdu translation CCRUM, Ministry of Health \& Family Welfare, Government of India, New Delhi. 2008; 501-507. 